\title{
Kaidah Penafsiran Puisi Perjanjian Lama
}

\author{
Paulus Dimas Prabowo \\ Sekolah Tinggi Teologi Injili Indonesia - Yogyakarta \\ Korespondensi: paul110491@gmail.com
}

\begin{abstract}
Abstrak: Allah yang begitu kreatif tidak hanya memakai beragam jenis orang untuk menuliskan wahyu-Nya, tetapi juga memakai bermacam jenis sastra (genre) yang dikenal dalam peradaban manusia. Itu sebabnya, metode dalam mempelajari dan menganalisa sebuah teks bisa berbeda satu sama lain, tergantung jenis sastranya. Belakangan, hasil-hasil penelitian biblika telah melirik jenis sastra sebagai pertimbangan utama dalam menggali dan menemukan makna. Hal senada juga seyogyanya dianut oleh para peneliti biblika di negeri ini. Artikel ini bertujuan untuk menjelaskan bagaimana menganalisis teks alkitabiah dalam genre puisi Perjanjian Lama. Sebab, tidak jarang pelajar Alkitab menggali buku puisi dengan prosedur yang tidak semestinya. Cara penggalian kitab puisi tidak sama dengan cara penggalian kitab narasi, epistolari, dan genre lainnya. Oleh karena itu penulis mencoba menyajikan suatu cara untuk menganalisis kitab-kitab puisi Perjanjian Lama, guna membekali pembaca dengan prosedur yang tepat dalam menggali teks-teks puisi Perjanjian Lama. Metode yang dipakai dalam artikel ini ialah studi literatur, di mana data-data dalam artikel ini diperoleh dari beragam sumber dengan topik terkait.
\end{abstract}

Kata kunci: puisi, kaidah, penafsiran

\begin{abstract}
God who is so creative not only used various types of people to write His revelations, but also used various types of literature (genre) known in human civilization. That is why, the methods of studying and analyzing a text may differ from one another, depending on the type of literature. Recently, the results of biblical research have looked at the type of literature as the main consideration in finding the meaning. The same thing should also be adopted by biblical researchers in this country. This article aims to explain how to analyze biblical texts in the genre of Old Testament poetry. Because, it is not uncommon for students to find poetry book Bibles with improper procedures. Writing poetry is not the same as telling stories about narrative, epistolary, and other genres. Therefore, the writer tries to present a way to analyze the Old Testament poetry books, in order to equip the readers with the right procedure in capturing the Old Testament poetry texts. The method used in this article is to find a literature study, where the data in this article were obtained from various sources with related topics.
\end{abstract}

Keywords: poetry, principle, interpretation 


\section{PENDAHULUAN}

Puisi Perjanjian Lama mengandung keunikan, dimana pesan teologis di dalamnya disampaikan melalui kata-kata yang disusun secara estetis dengan melibatkan emosi penulis. Kitab Ayub, Mazmur, Amsal, Pengkhotbah, Kidung Agung, bahkan Yesaya dan dua belas kitab nabi kecil, secara umum ditulis dalam bentuk sastra puisi. ${ }^{1}$ Konten puitis di dalamnya begitu mengagumkan untuk disimak. Calvin misalnya, memiliki kekaguman tersendiri terhadap Kitab Mazmur dengan menggambarkannya sebagai 'sebuah kaca yang menyatakan semua emosi pada manusia' di mana Roh Kudus menarik semua kesedihan, ketakutan, keraguan, harapan, kepedulian, kebingungan, dan bentuk emosi apapun kepada kehidupan manusia. ${ }^{2}$

Beberapa masalah telah dijumpai terkait penafsiran puisi Perjanjian Lama. Masalah pertama ialah depuisisasi. Klein mengingatkan ada bahaya mengabaikan kaidah-kaidah puisi yang terkandung di dalam Alkitab sehingga penafsir bisa kehilangan 'rasa nikmat' dan sulit mendengar kebenaran di dalam kitab puisi secara lebih jelas. ${ }^{3}$ Misalnya jika seorang penafsir mengabaikan adanya paralelisme dan permainan bunyi, maka akan menilai puisi terjemahan LAI sebagai teks yang hambar.

Masalah kedua ialah disfungsi. Nida menjelaskan bahwa bentuk puitis harus disadari fungsinya. Misalnya pemakaian bentuk puisi dalam Ucapan Kenabian yang berisi ultimatum tersebut tidak difungsikan untuk membuat katakata nubuatan tersebut menjadi mudah diingat atau untuk memperindah suatu ucapan. ${ }^{4}$ Jangan sampai fungsi estetis didewakan karena berpotensi mengaburkan tujuan utama sebuah teks.

${ }^{1}$ J.P. Fokkelman, Reading Biblical Poetry: An Introductory Guide (Kentucky: Wesminster John Knox Press, 2001), 2.

${ }^{2}$ John Calvin, Commentary On Psalms, Volume I (Michigan: Christian Classics Etheral Library, n.d.), 23.

${ }^{3}$ Robert I. Hubbard Jr. William W. Klein, Craig L. Blomberg, Introduction To Biblical Interpretation 2, ed. Chilianha Jusuf (Malang: Literatur SAAT, 2017), 116.

${ }^{4}$ Eugene A Nida, "Poetry and The Bible Translator," The Bible Translator 33, no. 4 (1982): 438.
Masalah ketiga ialah distansi. Distansi bisa dimaknai sebagai kegagalan penafsir untuk memisahkan dirinya dari presuposisi yang dipercayainya ketika menafsirkan dan menilai suatu teks, sehingga kehilangan kebenaran sesungguhnya dan/atau kegagalan penafsir menemukan afeksi dan devosi firman Allah yang hidup karena menganggap puisi Perjanjian Lama sekadar karya sastra biasa pada umumnya. ${ }^{5}$

Melihat masalah tersebut, maka perlu adanya pemahaman mengenai metode dalam menafsirkan puisi Perjanjian Lama, sehingga para pelajar Alkitab mampu menemukan makna yang terkandung dalam sebuah teks, yakni apa yang Allah maksudkan ketika mewahyukan firman kepada penulis kitab. Pertanyaan masalah dalam artikel ini ialah: bagaimana kaidah penafsiran puisi Perjanjian Lama? Maka, artikel ini hendak menyajikan kaidah penafsiran puisi Perjanjian Lama dengan disertai contoh dalam setiap tahapannya.

Sebelumnya telah ada beberapa hasil penelitian tentang hermeneutika Perjanjian Lama. Pertama, terkait hermeneutika genre narasi. Aaron Heng Yeon Chan telah menulis artikel yang mengulas tentang hermeneutika teks Perjanjian Lama dengan genre narasi. Di dalamnya terdapat kajian beberapa karya tentang etika narasi Perjanjian Lama yang berpengaruh untuk dibahas kelemahan-kelemahan dan kekurangan-kekurangannya, lalu mengusulkan cara yang layak untuk mendekati narasi Perjanjian Lama secara etis. ${ }^{6}$ Kedua, terkait hermeneutika genre sastra hikmat. Beberapa karya di antaranya ditulis oleh Sonny Eli Zaluchu yang menawarkan pola hermeneutika sastra hikmat yaitu dengan menentukan kategori sastra, menangkap gagasan utama penulis, melihat teks di dalam konteks, dan memperhatikan gaya bahasa, sehingga akan menolong penafsir mengangkat makna dari isi

${ }^{5}$ D.A Carson, Exegetical Fallacies (Surabaya: Momentum, 2018), 126.

${ }^{6}$ Aaron Heng Yeon Chan, "Etika Dalam Narasi Perjanjian Lama," Veritas: Jurnal Teologi Dan Pelayanan 14, no. 2 (2013): 199-220. 
kitab-kitab sastra Hikmat. ${ }^{7}$ Ada juga karya Sia Kok Sin yang secara khusus memaparkan cara menganalisis Kitab Amsal (sastra hikmat) dengan model topikal. ${ }^{8}$ Ketiga, karya-karya terkait Kitab Mazmur. Martus A. Maleachi telah menulis artikel tentang Kitab Mazmur yang membahas tentang karakteristik mazmur dan langkahlangkah menafsirkan Kitab Mazmur, meliputi tujuh langkah praktis yang dijabarkan secara singkat. ${ }^{9}$ Berthold Anton Pareira juga telah menulis tentang mazmur dengan mengaitkan kitab Mazmur dengan pembinaan integral jemaat yang terwujud melalui ibadah, nyanyian/musik, serta seni bangunan, sehingga nampak bahwa karya seni juga bisa berkontribusi dalam upaya pembinaan jemaat. ${ }^{10}$

Rupanya belum banyak artikel yang membahas mengenai hermeneutika genre tertentu dalam Perjanjian Lama. Dapat dilihat bahwa hermeneutika genre narasi dan sastra hikmat yang banyak dibahas. Dengan demikian, kebaruan artikel ini terletak pada jenis genre yang dibahas, yakni genre puisi, dan kedalaman pembahasan yang dilakukan. Keberadaan artikel ini kiranya menambah perbendaharaan literatur mengenai hermeneutika Perjanjian Lama dan menyediakan panduan yang bisa dipakai oleh para pelajar Alkitab yang tertarik menggali teks puisi Perjanjian Lama.

\section{METODE}

Jenis penelitian yang dipakai dalam artikel ini adalah penelitian kualitatif dengan metode studi literatur. Data-data dikumpulkan sesuai topik terkait dari berbagai literatur yang relevan, teristimewa dari buku-buku hermeneutik yang membahas genre puisi. Penyajian hasil penelitian

${ }^{7}$ Sonny Eli Zaluchu, "Pola Hermenetik Sastra Hikmat Orang Ibrani,” Evangelikal: Jurnal Teologi Injili Dan Pembinaan Warga Jemaat 3, no. 1 (2019): 21-29.

${ }^{8}$ Kok Sin Sia, "Pendekatan Topikal Dalam Menafsirkan Kitab Amsal," Jurnal Theologia Aletheia 20, no. 4 (2018): 1-28.

${ }^{9}$ Martus A Maleachi, "Karakteristik Dan Berbagai Genre Dalam Kitab Mazmur," Veritas: Jurnal Teologi Dan Pelayanan 13, no. 1 (2012): 121-40.

10 Berthold Anton Pareire, "Mazmur Dan Pembinaan Integral Pelayan Firman," Studia Philosophica Et Theologica 2, no. 1 (2002): 44-53. dilakukan secara deskriptif, dengan urutan yang sistematis. Pertama, berisi penjelasan mengenai puisi Perjanjian Lama meliputi lapisan hirarkis, karakteristik, dan jenis-jenisnya. Dengan demikian pembaca akan dibuka wawasannya mengenai sifat dan keragaman jenis puisi dalam Perjanjian Lama. Kedua, berisi pemaparan mengenai hasil penelitian tentang kaidah penafsiran puisi Perjanjian Lama, menyangkut langkah-langkah penafsiran yang diperoleh dari penyarian beberapa literatur. Hasil penelitian akan disajikan secara urut dan sistematis.

\section{PEMBAHASAN}

\section{Pengenalan Puisi Perjanjian Lama}

Puisi adalah ekspresi konkret dan artistik dari pikiran manusia dalam bahasa yang emosional dan ritmis. ${ }^{11}$ Ada lima kitab di dalam Perjanjian Lama yang secara umum disebut sebagai Kitab Puisi, yakni Ayub, Mazmur, Amsal, Pengkhotbah, dan Kidung Agung. Namun hampir setengah dari Perjanjian Lama ditulis dengan bentuk puitis. ${ }^{12}$ Bahkan beberapa bagian dari kitab-kitab Perjanjian Baru pun bersifat puitis. ${ }^{13}$ Fakta ini menunjukkan bahwa puisi merupakan jenis kesusastraan yang cukup besar porsinya di dalam Alkitab.

Puisi Ibrani memiliki kesamaan dengan puisi Timur Dekat Kuno, baik dari segi struktur maupun kontennya. Ada beberapa contoh yang dapat ditunjukkan. Pertama, antara Mazmur 54:3-4 dengan Ishtar 2:43-44 (Mesopotamia). ${ }^{14}$ Dalam Mazmur 54:3-4 dikatakan sebagai berikut:

"Ya Allah, selamatkanlah aku karena nama-Mu, berilah keadilan kepadaku karena keperkasaan-Mu!

${ }^{11} \mathrm{H}$. W. Provence, "Lyric Poetry in the Bible," Review and Expositor 33, no. 4 (1936): 402.

${ }^{12}$ Milton S. Terry, Biblical Hermeneutics: A Treatise On The Interpretation Of The Old And New Testaments (New York: Philips and Hunt, 1999), 90.

${ }^{13}$ William L. Wonderly, "Poetry In The Bible Challenge to Translators," The Bible Translator 38, no. 2 (1987): 206.

${ }^{14}$ Anna Elise Zernecke, "Mesopotamian Parallels to the Psalms," in The Oxford Handbook of the Psalms, ed. William P. Brown (New York: Oxford Unity Press, 2014), 28. 
Ya Allah, dengarkanlah doaku, berilah telinga kepada ucapan mulutku."

Sedangkan di dalam Ishtar 2:43-44 dikatakan sebagai berikut:

"Lihatlah aku, Ibu, dan terimalah permohonanku! Lihatlah dengan setia padaku dan dengarkan doaku!”

Contoh-contoh di atas memperlihatkan bahwa keduanya berisi permohonan agar doanya dikabulkan, meskipun berbeda nama sesembahan.

Kedua, antara Mazmur 92:10 dengan KTU ${ }^{15}$ 1.2 IV 7-10 (Ugarit Baal Cycle) yang keduanya mengagungkan kekuatan dan keabadian. ${ }^{16}$ Dalam Mazmur 92:10 dikatakan:

"Sebab, sesungguhnya musuh-Mu, ya TUHAN, sebab, sesungguhnya musuh-Mu akan binasa, semua orang yang melakukan kejahatan akan diceraiberaikan.”

Sedangkan dalam KTU 1.2 IV 7-10 dikatakan:

"Sekarang, musuhmu, Baal,

sekarang kau akan membunuh musuhmu, sekarang kamu akan memusnahkan musuhmu."

Dapat disaksikan, bahwa kebinasaan musuh menjadi penekanan keduanya.

Pembandingan Mazmur dengan dua syair Timur Dekat Kuno lainnya menunjukkan bahwa rupanya struktur (jumlah baris) dan konten puisi Ibrani lazim dipakai di bangsa semitik lainnya.

\section{Lapisan Hirarkis Puisi Ibrani}

Seperti puisi pada umumnya, struktur puisi Ibrani mengenal tingkatan bagian atau lapisan hirarkis. Fokkelman menjelaskan ada sembilan lapisan hirarkis di dalam puisi, yakni: bunyi, silabel/suku kata, kata, kola, ayat, strofa, stanza,

\footnotetext{
${ }^{15} \mathrm{KTU}$ adalah singkatan dari Keilalphabetische Texte aus Ugarit, yaitu teks Ugarit Mengenai Mitologi Baal.

${ }^{16}$ Mark S. Smith, "Canaanite Backgrounds to the Psalms," in The Oxford Handbook of the Psalms, ed. William P. Brown (New York: Oxford Unity Press, 2014), 45.
}

bagian/sections, puisi. ${ }^{17}$ Unit terbesar adalah puisi secara menyeluruh, sedangkan unit terkecil adalah bunyi. Beberapa istilah yang sering muncul dalam karya-karya terkait puisi Perjanjian Lama di antaranya ialah kola, strofa, dan stanza. Kola adalah sebuah baris puisi dan kadang disebut juga dengan stich. ${ }^{18}$ Satu kola/baris haruslah sebuah kalimat yang lengkap. ${ }^{19}$ Stanza adalah satu subdivisi sebuah puisi, sedangkan strofa adalah subunit di dalam stanza. ${ }^{20}$ Jadi, sebuah stanza bisa terdiri dari beberapa strofa.

\section{Karakteristik Puisi Ibrani}

Pada dasarnya ada beragam pendapat mengenai karakteristik puisi Ibrani. Gillingham berpendapat setidaknya ada empat corak umum dari puisi Ibrani, meliputi: kesederhanaan gaya, bahasa figuratif, makna ganda, dan membangkitkan respon. ${ }^{21}$ Kesederhanaan gaya dalam artian bahwa jumlah kata per baris tidak terlalu banyak. Bahasa figuratif berisi ungkapan dan ucapan yang penuh penggambaran. Makna ganda berarti bahwa terdapat makna literal dan kiasan dalam sekali penuturan. Puisi Ibrani membangkitkan respon, sebab puisi Ibrani begitu emosional yang dapat menyentuh perasaan dan respon pembaca. Sedangkan menurut Peterson tiga penciri utama puisi Ibrani adalah paralelisme, ritme (irama) dan gaya bahasa (figure of speech). ${ }^{22}$ Kesejajaran merupakan kesamaan pola antar baris, ritme merupakan irama berupa batasan jumlah kata atau suku kata

${ }^{17}$ Fokkelman, Reading Biblical Poetry: An Introductory Guide, 30

${ }^{18}$ Wilfred G. E. Watson, "Classical Hebrew Poetry: A Guide To It's Techniques," Journal for the Study of the Old Testament, 1986, 12.

${ }^{19}$ Alveiro Niccaci, "Analyzing Biblical Hebrew Poetry," Journal for the Study of the Old Testament 74 (1997): 81.

${ }^{20}$ Watson, "Classical Hebrew Poetry: A Guide To It's Techniques," 161.

${ }^{21}$ S.E. Gillingham, The Poems and Psalms of the Hebrew Bible, ed. P.R. Ackroyd \& G.N. Stanton (New York: Oxford University Press, 1994), 21-22.

${ }^{22}$ David L. Peterson \& Kent Harold Richards, Interpretting Hebrew Poetry (Minneapolis: Fortress Press, 1992), 14. 
tiap baris, dan gaya bahasa terkait penggambaran.

Longman menyebutkan bahwa puisi Ibrani dicirikan dua hal saja, yakni paralelisme dan imageri. ${ }^{23}$ Sedangkan Osborne lebih setuju jika corak puisi Ibrani meliputi: pola-pola metrik, paralelisme atau kesejajaran, dan bahasa atau gambaran. ${ }^{24}$ Sementara Klein, Blomberg, dan Hubbard berpendapat ada tiga corak yang meliputi: bunyi, struktur, dan bahasa. ${ }^{25}$ Hingga kini belum ada konsensus mengenai corak yang baku dalam puisi Ibrani. Melihat beragam pendapat di atas, maka artikel ini menyajikan beberapa corak yang pada umumnya diterima sebagai penciri puisi Ibrani, yakni: permainan bunyi, ritme, bahasa figuratif, dan paralelisme.

\section{Permainan Bunyi}

Sebagaimana lazimnya, permainan bunyi tidak bisa dipisahkan dari puisi. Gillingham menyebutnya sebagai phonetic device dan plays on words. ${ }^{26}$ Setidaknya ada empat jenis permainan bunyi dalam puisi, yakni paronomasia, aliterasi, asonansi, dan akrostik. ${ }^{27}$ Paronomasia adalah suatu gaya pengulangan kata-kata yang bunyinya mirip, tetapi artinya tidak harus sama. ${ }^{28}$ Salah satu contohnya ada di dalam Yesaya 5:7b, yakni:

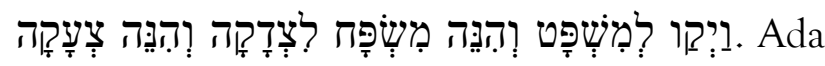

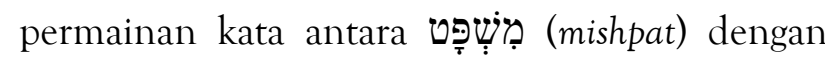

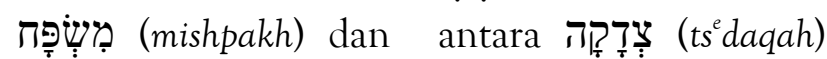

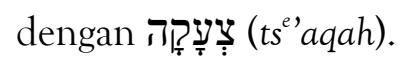

Aliterasi adalah sebuah bentuk pengulangan konsonan $^{29}$ dan contohnya dapat dilihat dalam

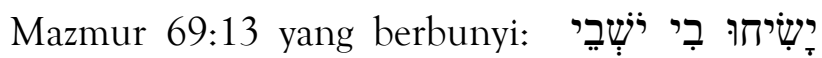

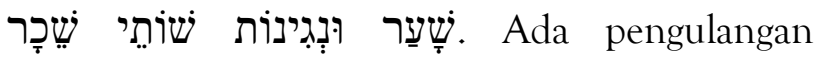
konsonan ש שָׁעַר (shin) dalam karar) dan שָָׁכר (sh $\left.{ }^{e} k a r\right)$.

Asonansi adalah bentuk pengulangan bunyi vokal, $^{30}$ dan contohnya terlihat di dalam

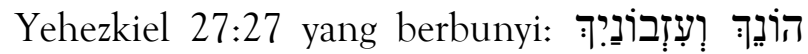

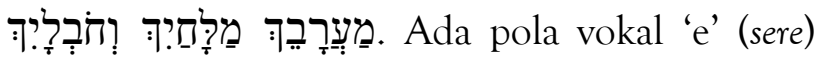

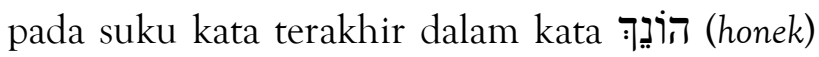

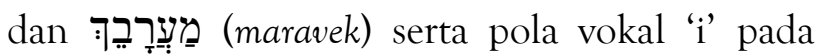

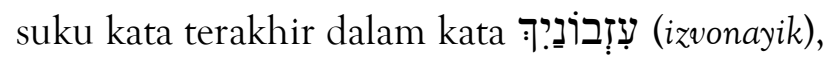

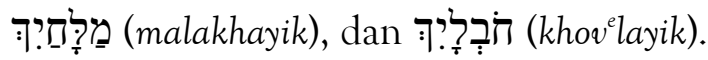

Akrostik adalah sebuah puisi di mana huruf awal dari setiap baris berturut-turut membentuk kata, frase atau pola. ${ }^{31}$ Contohnya adalah Mazmur 119, dimana ada 176 ayat dengan 22 bait, dan setiap bait berisi 8 ayat dan awal ayat ditulis dengan abjad Ibrani secara berurutan. Beberapa contoh lain adalah Amsal 31:10-31 dan Ratapan 1-4.

\section{Ritme}

Ritme kadang disebut juga dengan irama, yang dibatasi jumlah suku kata tertentu setiap barisnya. ${ }^{32}$ Ada juga yang mengaitkan ritme dengan matra (meter). Masalahnya hingga saat ini para ahli masih berbeda pendapat dalam menyusun struktur ritme, terlebih lagi belum ada seorang pun yang berhasil menemukan formula untuk mengungkap rahasia dari ritme Semitik. ${ }^{33}$

${ }^{29}$ S.E. Gillingham, The Poems and Psalms of the Hebrew Bible (New York: Oxford University Press, 1994), 192.

${ }^{30}$ Gillingham, The Poems and Psalms of the Hebrew Bible, 1994, 192.

${ }^{31}$ M. D Metzger, Bruce M. and Coogan, Oxford Companion to the Bible (New York: Oxford University Press, 1999), 6.

${ }^{32}$ William A Smalley, "Translating The Poetry of the Old Testament," The Bible Translator 26, no. 2 (1975): 203.

${ }^{33}$ Osborne, Spiral Hermeneutika: Pengantar Komprehensif Bagi Penafsiran Alkitab, 268. 


\section{Bahasa Figuratif}

Bahasa figuratif atau bahasa gambaran dipakai penyair untuk merangsang berbagai indra dan emosi pembaca supaya pembaca turut merasakan dan mengalami apa yang penyair sedang sampaikan melalui kata-kata figuratif mereka. ${ }^{34}$ Ada banyak macam bahasa figuratif yang tidak mungkin disebutkan semuanya dalam karya ini. ${ }^{35}$ Namun hanya beberapa contoh yang hendak dipaparkan dalam artikel ini agar tidak memakan banyak waktu dan tempat. Contoh yang dipaparkan adalah yang dianggap paling banyak dipakai.

Pertama adalah simile, yakni sebuah gaya bahasa yang memperbandingkan dua hal dengan menggunakan kata-kata seperti "seperti" atau "sebagaimana." ${ }^{36}$ Contohnya Kidung Agung 2:2 "Seperti bunga bakung di antara duri-duri, demikianlah kekasihku di antara gadis-gadis."

Kedua adalah metafora, yakni perbandingan antara dua hal dengan cara yang akan memberikan kunci bagi pembaca untuk mengerti arti dari penggambaran tersebut. ${ }^{37}$ Metafora tidak memakai kata "seperti" atau "sebagaimana." Contohnya Mazmur 84:12, "Sebab TUHAN Allah adalah matahari dan perisai."

Ketiga adalah metonimia, yakni cara menyebutkan sesuatu secara tidak langsung, yaitu dengan menyebutkan benda atau sesuatu yang lain yang erat hubungannya dengan yang dimaksudkan itu. ${ }^{38}$ Contohnya Imamat 26:25, "Aku akan mendatangkan ke atasmu suatu pedang."

Keempat adalah personifikasi, yakni penggambaran benda mati yang bertindak seperi

\footnotetext{
${ }^{34}$ William W. Klein, Craig L. Blomberg, Introduction To Biblical Interpretation 2, 167.

35 Terry, Biblical Hermeneutics: A Treatise On The Interpretation Of The Old And New Testaments; Bullinger, Figures of Speech Used In The Bible: Explained and Illustrated.

${ }^{36}$ William W. Klein, Craig L. Blomberg, Introduction To Biblical Interpretation 2, 168.

37 Maleachi, "Karakteristik Dan Berbagai Genre Dalam Kitab Mazmur,” 124.

${ }^{38}$ Dendy Sugono, Kamus Bahasa Indonesia (Jakarta: Pusat Bahasa, 2008), 952.
}

manusia. ${ }^{39}$ Contohnya Kejadian 4:10, "Suara darah adikmu itu berteriak kepada-Ku dari tanah." Masih banyak jenis bahasa figuratif lainnya dan perlu studi khusus untuk menjabarkannya.

\section{Paralelisme}

Pada pertengahan abad ke-17, Bishop Robert Lowth memperkenalkan prinsip kesejajaran baris yang dikenal dengan nama paralelisme, dimana secara sederhana ia menemukan bahwa setiap baris puisi Ibrani memiliki setidaknya dua bagian, di mana bagian kedua melengkapi pikiran di bagian pertama. ${ }^{40}$ Beberapa jenis paralelisme perlu dijelaskan secara singkat di dalam bagian ini.

Pertama adalah paralelisme sinonimi, yakni suatu kesejajaran dimana baris kedua mengulang baris pertama dengan sedikit atau tidak ada makna yang ditambahkan. ${ }^{41}$ Contohnya Mazmur 2:3 sebagai berikut:

\section{"Marilah kita memutuskan belenggu-belenggu mereka, \\ dan membuang tali-tali mereka dari pada kita.”}

Kata 'memutuskan' bersinonim dengan 'membuang', dan kata 'belenggu' bersinonim dengan 'tali.'

Kedua adalah paralelisme sintesis, yakni kesejajaran dimana baris pertama dan baris kedua saling memenuhi. ${ }^{42}$ Dalam jenis ini, ada unsur saling melengkapi. Contohnya Mazmur 1:3 sebagai berikut:

"Ia seperti pohon yang ditanam di tepi aliran air, yang menghasilkan buahnya pada musimnya, dan yang tidak layu daunnya, apa saja yang diperbuatnya berhasil.”

${ }^{39}$ Watson, "Classical Hebrew Poetry: A Guide To It's Techniques,” 270.

${ }^{40}$ T.H. Robinson, "Hebrew Metre and Old Testament Exegesis," The Expository Times 54, no. 9 (1942): 246.

${ }^{41}$ Osborne, Spiral Hermeneutika: Pengantar Komprehensif Bagi Penafsiran Alkitab, 264.

${ }^{42}$ Richards, Interpretting Hebrew Poetry, 25. 
Ada peningkatan pemikiran dalam ayat tersebut: penanaman, berbuah, bertahan, dan keberhasilan total.

Ketiga adalah paralelisme antitesis, yakni kesejajaran dimana ide pada baris pertama dan kedua dikontraskan berlawanan satu sama lain. ${ }^{43}$ Contohnya Amsal 3:1 sebagai berikut:

"Hai anakku, janganlah engkau melupakan ajaranku,

dan biarlah hatimu memelihara perintahku.”

Baris pertama menekankan kata 'melupakan' sedangkan baris kedua menunjukkan gagasan yang kontras dengan kata 'memelihara.'

Keempat adalah paralelisme emblematik yakni kesejajaran analogis, yang memakai kata perbandingan guna menyatukan dua pikiran dari dunia yang berbeda. ${ }^{44}$ Contohnya Mazmur 42:2 sebagai berikut:

"Seperti rusa yang merindukan sungai yang berair, demikianlah jiwaku merindukan engkau, ya Allah."

Kerinduan pemazmur kepada Allah dianalogikan seperti rusa yang merindukan sungai berair.

Kelima adalah paralelisme repetitif, yakni kesejajaran yang bercirikan adanya sebagian kalimat di baris pertama yang diulang di baris kedua dan seterusnya. ${ }^{45}$ Contohnya Mazmur 96:1 yang berbunyi:

"Nyanyikanlah (shiru) nyanyian baru bagi TUHAN, menyanyilah (shiru) bagi TUHAN, hai segenap bumi!"

Instruksi "nyanyikanlah" dan "menyanyilah" diulangi di awal baris kedua dalam ayat yang sama dan menunjukkan adanya repetisi.

Keenam ialah chiasme, yakni sebuah perangkat struktur umum lain yang di dalamnya susunan kata dari baris paralel ditempatkan dalam urutan terbalik dengan baris sebelumnya (a b | b' a'). ${ }^{46}$ Contohnya ialah Amos 1:2a, Guide, 25.

${ }^{43}$ Fokkelman, Reading Biblical Poetry: An Introductory

${ }^{44}$ III, Bagaimana Menganalisa Kitab Mazmur, 119.

${ }^{45}$ III, 119.

${ }^{46}$ William W. Klein, Craig L. Blomberg, Introduction To Biblical Interpretation 2, 158.
"TUHAN mengaum dari Sion dan dari Yerusalem Ia memperdengarkan suara-Nya." Sering digambarkan seperti ini:
A TUHAN mengaum
B dari Sion
B' dari Yehuda
A' Ia memperdengarkan suara-Nya

Chiasme tidak hanya dijumpai pada baris-baris tunggal dalam sebuah ayat, tetapi pada cakupan yang lebih besar, bahkan di keseluruhan kitab. ${ }^{47}$

\section{Jenis-jenis Puisi Ibrani}

Osborne menyebutkan beberapa jenis puisi. Pertama, Nyanyian-nyanyian Perang, di dalam Keluaran 15:1-8; Bilangan 10:35-36; 21:27-30; Hakim-Hakim 7:18, 20; 1 Samuel 18:7, 21:11, 29:5. Kedua, Kidung Cinta seperti dalam Kidung Agung. Ketiga, Ratapan (baik individual maupun kolektif) seperti yang terdapat di dalam beberapa Mazmur dan 2 Samuel 1:17-27; 3:33-34. Keempat, Himne atau Nyanyian Pujian yang banyak dijumpai dalam Mazmur. Kelima, Himne Ucapan Syukur (baik individual maupun kolektif) dalam Mazmur. Keenam, Nyanyian Perayaan atau Penegasan yang juga terdapat dalam Mazmur. Ketujuh, Mazmur Hikmat dan Pengajaran, di dalam Mazmur 1, 36, 37, 49, 73, 112, 127, 128, dan 133, dan khusus Mazmur 1, 19, 119 sebagai Mazmur Taurat. Kedelapan Mazmur Kutukan seperti dalam Mazmur 12, 35, $52,57-59,69,70,83,109,137,140 .{ }^{48}$

Sebagai tambahan, Longman dan Bullock secara khusus membahas jenis-jenis mazmur. ${ }^{49}$ Beberapa di antaranya ialah mazmur pujian, mazmur ratapan, mazmur ucapan syukur, mazmur iman, mazmur raja, mazmur hikmat, mazmur Taurat, dan mazmur kutukan. Setiap jenis mazmur memiliki karakteristiknya masingmasing.

${ }^{47}$ William W. Klein, Craig L. Blomberg, 160.

${ }^{48}$ Osborne, Spiral Hermeneutika: Pengantar Komprehensif Bagi Penafsiran Alkitab, 270-76.

${ }^{49}$ III, Bagaimana Menganalisa Kitab Mazmur, 19-36; C. Hassell Bullock, Encountering the Book of Psalms: A Literary and Theological Introduction (Grand Rapids, Michigan: Baker Academic, 2001). 


\section{Langkah-langkah Penafsiran Puisi Perjanjian Lama}

Aspek kesusatraan menjadi dasar dalam menganalisis puisi Perjanjian Lama. Istilah yang umum dipakai ialah 'pendekatan genre,' yang melibatkan analisis retoris atau rhetorical criticism. $^{50}$ Ada beberapa usulan langkah praktis dalam menganalisa perikop puitis. ${ }^{51}$ Dari beragam usulan tersebut, penulis menyarikan langkah-langkah praktis menganalisa perikop puisi. Ada lima langkah praktis yang bisa disebut dengan formula 5T, yakni: 1) Temukan paralelisme; 2) Tentukan strukur keseluruhan puisi; 3) Telusuri bahasa figuratif; 4) Tinjau latar belakang historis; 5) Temukan tema teologi.

\section{Langkah 1: Temukan Paralelisme}

Langkah pertama ialah menemukan kesejajaran atau paralelisme di dalam sebuah ayat (kadang di dalam dua ayat yang memuat satu kesatuan gagasan). Identifikasi paralelisme memiliki beberapa tujuan. Pertama, membantu penafsir menemukan ide sentral suatu ayat. Long menjelaskan bahwa salah satu efek paralelisme dalam mazmur adalah penekanan yang menggarisbawahi ide utama unit, apakah itu dicapai dengan pengulangan (paralelisme sinonim) atau sebaliknya (paralelisme antitesis). ${ }^{52}$

${ }^{50}$ Rethorical Crriticism melibatkan analisis yang mendalam terhadap unsur kesenian, estetika, dan stilistika sebuah teks. Pendekatan ini secara luas diaplikasikan pada semua jenis Mazmur saat ini. Ryan Cook, "Prayers That Form Us: Rhetoric and Psalms Interpretations,” JSOT 39, no. 4 (2015): 452.

${ }^{51}$ Grant Osborne, Spiral Hermeneutika: Pengantar Komprehensif bagi Penafsiran Alkitab, pen. Elifas Gani (Surabaya: Momentum, 2018), 279-282; William W. Klein, dkk, Introduction To Biblical Interpretation 2, peny. Chilianha Jusuf, pen. Timotius Lo (Malang: Literatur SAAT, 2017), 259-261; Thomas G. Long, "Preaching Psalms" dalam The Oxford Handbook of Psalms, ed. William P. Brown (New York: Oxford University Press, 2012), 558566; D. Brent Sandy dan Ronald R. Giese Jr, Cracking Old Testament Codes: A Guide to Interpreting the Literary Genres of the Old Testament (Tennesse: Broadman \& Holman Publisher, 1995), 197-228.

${ }^{52}$ Thomas G. Long, "Preaching Psalms," in The Oxford Handbook of Psalms, ed. William P. Brown (New York: Oxford University Press, 2012), 558.
Bahkan Petersen menyebut bahwa paralelisme membantu penafsir mengidentifikasi 'isi hati' penulis. ${ }^{53}$ Kedua, perhatian terhadap paralelisme mencegah penafsir dari kesalahan penafsiran. ${ }^{54}$ Contohnya Mazmur 22:13 yang berbunyi:

Banyak lembu jantan mengerumuni aku, Banteng-banteng dari Basan mengepung aku

Baris pertama (A) dan kedua (B) menyebutkan dua jenis binatang yang berbeda. Penafsir tidak bisa menafsirkan induk kalimat dan anak kalimat secara berbeda dengan berpikir bahwa pemazmur sedang menghadapi dua jenis musuh yang berbeda. Gagasan ayat tersebut ialah bahwa Daud sedang terkepung oleh kekuatan di luar dirinya.

Penafsir perlu juga menentukan jenis paralelisme apa yang terkandung dalam nats yang diteliti, apakah jenisnya sinonimi, sintesis, antitesis, emblematis, repetitif, dan khiasme. Apapun bentuk paralelismenya tetap saja dipahami satu gagasan dengan rumus baku $A=B$. Namun harus diingat bahwa 'terkadang baris $B$ menghasilkan nilai tambah, ekstensi, dan elaborasi, atau nuansa pemikiran yang diungkapkan dalam baris A. ${ }^{55}$ Bukan berarti baris B membawa gagasan baru, namun hanya menambah kesan estetis dan emosional.

Sebuah perikop atau puisi utuh bisa mengandung beberapa paralelisme. Penafsir harus mampu menemukan gagasan setiap paralelisme dan mencatatnya. Maka akan ditemukan beberapa gagasan dan jika memungkinkan, penafsir mengelompokkannya sesuai dengan rumpunnya. Gagasan-gagasan tersebut mendukung ide utama atau tema utama sebuah perikop.

Langkah 2: Tentukan Strukur Keseluruhan Puisi

Mengenali struktur membantu penafsir melihat keseluruhan retorika, makna utuh teks,

${ }^{53}$ Richards, Interpretting Hebrew Poetry, 34.

${ }^{54}$ Kenneth L. Bekker, "Praise," in Cracking Old Testament Codes: A Guide to Interpreting the Literary Genres of the Old Testament, ed. D. Brent Sandy dan Ronald R. Giese Jr (Tennesse: Broadman \& Holman Publisher, 1995), 226.

${ }^{55}$ Long, "Preaching Psalms," 558. 
dan unsur keindahan teks puisi. ${ }^{56}$ Bila sedang menganalisa sebuah mazmur, langkah paling mudah ialah menemukan jenis mazmur apa yang sedang dibaca. Hal ini dapat dilihat dari mood yang dibangun dan kosakata apa yang kerap muncul: apakah itu bernuansa ratapan, ucapan syukur, pengharapan atau doa, dan lain sebagainya. Biasanya setiap jenis mazmur memiliki susunan yang relatif sama di antara mazmur sejenis. Mazmur pujian, mazmur ratapan, mazmur ucapan syukur, dan jenis mazmur lain memiliki strukturnya masingmasing. Meskipun demikian harus diakui bahwa mazmur yang sejenis tidak selalu sama persis strukturnya. Bekker mengatakan bahwa walaupun mazmur-mazmur di dalam satu jenis mungkin sangat berbeda dalam hal kosa kata atau detail-detail di permukaan, namun mazmur yang jenis biasanya memiliki bentuk umum dan intensionalitas yang serupa. ${ }^{57}$

Struktur sebagaimana dijelaskan dalam bagian ini, bisa dipahami sebagai garis besar teks. Bentuk-bentuk puisi lain selain dari Kitab Mazmur susunannya lebih variatif dan tidak bisa mengikuti susunan jenis-jenis mazmur, misalnya saja Kidung Agung. Karena tidak ada formula khusus, maka hasil penelusuran struktur puisi bisa berbeda antara orang yang satu dengan yang lainnya. Aspek lain yang perlu diperhatikan saat mencermati puisi ialah jenis persona yang dipakai di dalam mazmur, apakah individual atau komunal. Dengan melihat jenis persona yang dipakai, penafsir akan mampu menguraikan teks dengan sudut pandang yang tepat. ${ }^{58}$ Misalnya saja dalam memahami mazmur ratapan yang ungkapkan secara individual akan berbeda yang diucapkan secara kolektif. Ratapan kolektif dilakukan dalam konteks ibadah Israel sedangkan ratapan individual adalah pengalaman pribadi dengan emosi mendalam.

${ }^{56}$ Rodney K. Duke, "Form and Meaning: MultiLayered Balanced Thought Structures in Psalm 24:4," Tyndalle Bulletin 62, no. 2 (2011): 215.

${ }^{57}$ Long, "Preaching Psalms," 559.

${ }^{58}$ Bekker, "Praise," 227.

\section{Langkah 3: Telusuri Bahasa Figuratif}

Sebuah puisi tentunya melimpah akan penggambaran dan kiasan. Model ini dikenal sebagai 'bahasa figuratif.' Pengertian tentang makna bahasa figuratif yang dipakai tidak hanya membantu penafsir mengetahui gagasan yang terkandung di dalamnya, namun juga menggiring penafsir pada emosi-emosi tertentu. Ada juga fungsi lain di balik pemakaian jenisjenis bahasa figuratif, misalnya metafora. Dengan mengutip pernyataan Newmark, Weiss menuliskan bahwa metafora, selain untuk menghibur pembaca, juga berfungsi untuk menggambarkan entitas (objek atau orang), peristiwa, kualitas, konsep atau kondisi pikiran lebih komprehensif, singkat, jelas, namun lebih kompleks dari penggunaan bahasa literal. ${ }^{59}$

Beberapa bahasa figuratif mengenai TUHAN bisa dipakai sebagai contoh. Misalnya di dalam Mazmur 23 terdapat metafora "TUHAN adalah gembalaku." Daud menggambarkan entitas TUHAN sebagai pemelihara, pembimbing, dan penyedia melalui sebuah gambaran yang begitu hidup, yakni 'gembala.' Perasaan yang diciptakan melalui metafora ini ialah ketenangan. Berbeda dengan nuansa yang dibangun dalam Mazmur 29:7 di mana 'suara TUHAN menyemburkan nyala api.' Penekanannya ialah keperkasaan TUHAN dan perasaan yang diciptakan ialah rasa takut dan hormat. Seorang penafsir perlu menelusuri lebih dalam lagi dengan memeriksa bahasa figuratif apa yang terkandung, lalu memaparkan maknanya.

\section{Langkah 4: Tinjau Latar Belakang Historis}

Mengetahui latar belakang peristiwa di balik penulisan teks puisi membantu penafsir memahami isi mazmur lebih mendalam. Ada dua cara untuk mengetahui latar belakang peristiwa di balik penulisan. Pertama melalui superskripsi. ${ }^{60}$ Superskripsi muncul pada ayat pertama di dalam mazmur. Contohnya dalam

${ }^{59}$ Andrea L. Weiss, Figurative Language in Biblical Prose Narrative: Metaphore in the Book of Samuel (Leiden: Koninklijke Brill NV, 2006), 121-22.

${ }^{60}$ Superskripsi adalah teks informatif yang mendahului tubuh utama lagu 
Mazmur 34:1; superskripsi di sana tertulis "Dari Daud pada waktu ia pura-pura tidak waras pikirannya di depan Abimelekh, sehingga ia diusir, lalu pergi." Tetapi perlu dipahami bahwa sangat sedikit mazmur yang menyertakan superskripsi pada tubuh mazmurnya.

Kedua, dengan mempelajari struktur dan konten puisi. ${ }^{61}$ Kadang kata-kata tertentu dan nuansa di dalam mazmur bisa memberi petunjuk mengenai latar belakang sejarahnya. Misalnya dalam Mazmur 42-43. Di dalam 42:4 pemazmur mengingat bagaimana ia berjalan maju dalam kepadatan manusia, mendahului mereka melangkah ke rumah Allah. Kemudian dalam 42:6 pemazmur teringat sungai Yordan dan pegunungan Hermon. Pasal 43:2 pun mencantumkan frasa 'membuang aku' yang menjelaskan bahwa pemazmur merasa terbuang. Dari konten mazmur tersebut dapat diduga bahwa pemazmur sedang berada di dalam pembuangan, jauh dari tanah perjanjian. Yang ketiga melalui teks narasi yang mendahului puisi. Contoh ini bisa dilihat dalam Yunus 2:1-9 di mana pasal 1:1-17 dan 2:1 menjelaskan sejarah peristiwa di baliknya.

\section{Langkah 5: Temukan Tema Teologi}

Langkah terakhir ialah menemukan prinsip teologis. Jika penggalian teks di langkah 1-4 ditulis dalam bentuk pernyataan eksegetis (lampau), maka setelahnya penafsir harus menuliskan kebenaran kekal dari teks, yakni prinsip teologis yang relevan sepanjang zaman. Mazmur dan puisi-puisi lain dalam Alkitab dipenuhi tema dan klaim teologis yang mengukir pandangan teologi di hati para pembaca. ${ }^{62}$ Long memberikan contoh dari Mazmur 51 mengenai pengakuan dosa Daud. Tema teologi yang disarankan ialah "realita dosa" di mana pemazmur tidak sedang menyangkali keberadaan dosa atau mengesampingkan kebenaran menyakitkan mengenai luka dan rasa bersalah, tetapi sebaliknya, ia berbicara secara jujur dan menyakitkan mengenai dosa, pelanggaran, dan rasa bersalah. ${ }^{63}$ Mazmur ini tidak bisa diaplikasikan untuk semua keadaan, namun diperuntukkan bagi mereka yang hancur hatinya karena menyadari dosa dan kesalahannya. Dan ketika itu terjadi, mazmur menyediakan bahasa yang berani dan jujur untuk digunakan dalam memohon pengampunan dan pembersihan pada saat itu. ${ }^{64}$

Untuk menemukan tema teologi, Osborne menyarankan para penafsir untuk pertama-tama menentukan jenis puisi atau mazmur yang sedang teliti, sebab setiap jenis puisi atau mazmur memiliki pesan tersendiri yang ingin disampaikan, misalnya saja mazmur ratapan yang berpusat pada pencobaan, mazmur kerajaan yang berpusat pada raja dan Mesias, dan lain sebagainya; kedua, penafsir melakukan eksegesis secara menyeluruh dengan memperhatikan natur puisi sebagaimana dijelaskan dalam langkah 1-4; ketiga, penafsir perlu memperhatikan tema kitab secara keseluruhan. ${ }^{65}$ Jenis-jenis puisi telah dijelaskan secara singkat di bagian sebelumnya, misalnya nyanyian-nyanyian Perang, kidung cinta ratapan (baik individual maupun kolektif), himne atau nyanyian pujian, himne ucapan syukur (baik individual maupun kolektif), nyanyian perayaan, mazmur hikmat dan Pengajaran, mazmur kutukan, dan lain sebagainya. Natur puisi yang dimaksud meliputi kesejajaran, struktur puisi, gaya bahasa, dan bisa juga melibatkan kesejarahan puisi.

Perlu dipahami bahwa tema-tema teologi dalam teks-teks puisi Perjanjian Lama sangatlah bervariasi dan tidak bisa disamakan dengan teologi sistematik. Waltner memberikan komentarnya mengenai tema teologi kitab Mazmur dengan mengatakan bahwa mazmur berisi perbendaharaan pengalaman yang dikumpulkan oleh beberapa generasi yang memelihara harapan dan kecemasan mereka saat mereka berpegang teguh pada nilai-nilai dan iman mereka kepada Tuhan, dan dengan demikian, mazmur mengandung dan ${ }^{62}$ Long, "Preaching Psalms," 559.

\footnotetext{
${ }^{63}$ Long, 565.

${ }^{64}$ Long, 565.

${ }^{65}$ Osborne, Spiral Hermeneutika: Pengantar

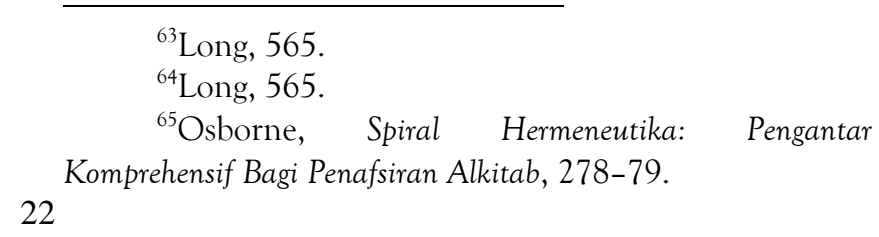


merenungkan berbagai macam dari topik. ${ }^{66}$ Ia mendaftarkan bahwa tema teologi kitab Mazmur membahas topik tentang Tuhan, keadaan manusia, dan umat Tuhan, termasuk ibadah, Kitab Suci, dan ketaatan. ${ }^{67}$ Puisi-puisi di dalam Kidung Agung maupun ucapan-ucapan para nabi tentunya akan menawarkan tema teologi yang jauh lebih beragam.

\section{KESIMPULAN}

Dapat disimpulkan bahwa puisi Perjanjian Lama memiliki kaidah penafsiran yang berbeda dari jenis sastra lain dalam Perjanjian Lama. Pemahaman yang benar mengenai kaidah penafsiran puisi Perjanjian Lama dapat menghindarkan penafsir dari masalah depuisisasi, disfungsi, dan distansi dalam penafsiran. Penafsir dituntut untuk cermat dalam melihat kesejajaran dan gaya bahasa yang terkandung di dalamnya, sehingga mampu menemukan pesan yang terkandung di dalam teks. Penelitian mengenai pendekatan sastra dalam Perjanjian Lama masih bisa terus dikembangkan oleh peneliti selanjutnya. Sebut saja genre hukum, nubuatan, dan apokaliptik yang bisa digarap secara cermat metode analisisnya.

\section{KEPUSTAKAAN}

Bekker, Kenneth L. "Praise." In Cracking Old Testament Codes: A Guide to Interpreting the Literary Genres of the Old Testament, edited by D. Brent Sandy dan Ronald R. Giese Jr. Tennesse: Broadman \& Holman Publisher, 1995.

Bullinger, E.W. Figures of Speech Used In The Bible: Explained and Illustrated. New York: Messrs E. \& J.B. Young \& Co, 1898.

Bullock, C. Hassell. Encountering the Book of Psalms: A Literary and Theological Introduction. Grand Rapids, Michigan:

${ }^{66}$ James H. Waltner, Believers Church Bible Commentary: Psalms (Scottdale, PA: Herald Press, 2006), 19.

\footnotetext{
${ }^{67}$ Waltner, 20.
}

Baker Academic, 2001.

Carson, D.A. Exegetical Fallacies. Surabaya: Momentum, 2018.

Chan, Aaron Heng Yeon. "Etika Dalam Narasi Perjanjian Lama." Veritas: Jurnal Teologi Dan Pelayanan 14, no. 2 (2013): 199-220.

Cook, Ryan. "Prayers That Form Us: Rhetoric and Psalms Interpretations." JSOT 39, no. 4 (2015).

Duke, Rodney K. "Form and Meaning: MultiLayered Balanced Thought Structures in Psalm 24:4." Tyndalle Bulletin 62, no. 2 (2011).

Fokkelman, J.P. Reading Biblical Poetry: An Introductory Guide. Kentucky: Wesminster John Knox Press, 2001.

Gillingham, S.E. The Poems and Psalms of the Hebrew Bible. Edited by P.R. Ackroyd \& G.N. Stanton. New York: Oxford University Press, 1994.

- The Poems and Psalms of the Hebrew Bible. New York: Oxford University Press, 1994.

H. W. Provence. "Lyric Poetry in the Bible." Review and Expositor 33, no. 4 (1936).

III, Tremper Longman. Bagaimana Menganalisa Kitab Mazmur. Malang: Literatur SAAT, 2012.

John Calvin. Commentary On Psalms. Volume I. Michigan: Christian Classics Etheral Library, n.d.

Long, Thomas G. "Preaching Psalms." In The Oxford Handbook of Psalms, edited by William P. Brown, 558-66. New York: Oxford University Press, 2012.

Maleachi, Martus A. "Karakteristik Dan Berbagai Genre Dalam Kitab Mazmur." Veritas: Jurnal Teologi Dan Pelayanan 13, no. 1 (2012): 121-40.

Metzger, Bruce M. and Coogan, M. D. Oxford Companion to the Bible. New York: Oxford University Press, 1999.

Niccaci, Alveiro. "Analyzing Biblical Hebrew Poetry." Journal for the Study of the Old Testament 74 (1997).

Nida, Eugene A. "Poetry and The Bible Translator." The Bible Translator 33, no. 4 (1982).

Osborne, Grant. Spiral Hermeneutika: Pengantar 
Komprehensif Bagi Penafsiran Alkitab. Surabaya: Momentum, 2018.

Pareire, Berthold Anton. "Mazmur Dan Pembinaan Integral Pelayan Firman." Studia Philosophica Et Theologica 2, no. 1 (2002): 44-53.

Richards, David L. Peterson \& Kent Harold. Interpretting Hebrew Poetry. Minneapolis: Fortress Press, 1992.

Robinson, T.H. "Hebrew Metre and Old Testament Exegesis." The Expository Times 54, no. 9 (1942).

Sia, Kok Sin. "Pendekatan Topikal Dalam Menafsirkan Kitab Amsal." Jurnal Theologia Aletheia 20, no. 4 (2018): 1-28.

Smalley, William A. "Translating The Poetry of the Old Testament." The Bible Translator 26, no. 2 (1975).

Smith, Mark S. "Canaanite Backgrounds to the Psalms." In The Oxford Handbook of the Psalms, edited by William P. Brown. New York: Oxford Unity Press, 2014.

Sugono, Dendy. Kamus Bahasa Indonesia. Jakarta: Pusat Bahasa, 2008.

Terry, Milton S. Biblical Hermeneutics: A Treatise On The Interpretation Of The Old And New Testaments. New York: Philips and Hunt, 1999.

Waltner, James H. Believers Church Bible Commentary: Psalms. Scottdale, PA: Herald Press, 2006.

Watson, Wilfred G. E. "Classical Hebrew Poetry: A Guide To It's Techniques." Journal for the Study of the Old Testament, 1986.

Weiss, Andrea L. Figurative Language in Biblical Prose Narrative: Metaphore in the Book of Samuel. Leiden: Koninklijke Brill NV, 2006.

William W. Klein, Craig L. Blomberg, Robert I. Hubbard Jr. Introduction To Biblical Interpretation 2. Edited by Chilianha Jusuf. Malang: Literatur SAAT, 2017.

Wonderly, William L. "Poetry In The Bible Challenge to Translators.” The Bible Translator 38, no. 2 (1987).

Zaluchu, Sonny Eli. "Pola Hermenetik Sastra Hikmat Orang Ibrani." Evangelikal: Jurnal Teologi Injili Dan Pembinaan Warga Jemaat 3,
Zernecke, Anna Elise. "Mesopotamian Parallels to the Psalms." In The Oxford Handbook of the Psalms, edited by William P. Brown. New York: Oxford Unity Press, 2014. 